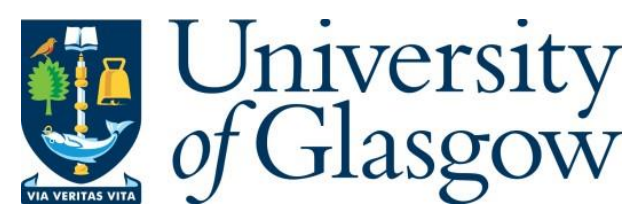

Mullen, S. (2016) The Scots Kirk of Colonial Kingston, Jamaica. Scottish Church History Society Records, 45.

There may be differences between this version and the published version. You are advised to consult the publisher's version if you wish to cite from it.

http://eprints.gla.ac.uk/156205/

Deposited on: 24 January 2018

Enlighten - Research publications by members of the University of Glasgow http://eprints.gla.ac.uk 


\section{The Scots Kirk of Colonial Kingston, Jamaica}

\section{STEPHEN MULLEN}

In June 1822, James Steele, a Minister in Jamaica, wrote to Duncan Macfarlan, a Minister in Drymen near Stirling, who later became principal of Old College. Steele was a student at Old College, now the University of Glasgow, in the early 1800s and perhaps met Macfarlan who was Dean of Faculties at the same time. In this letter, Steele referred to his recent appointment as minister of the presbyterian Scots Kirk in Kingston, the first establishment of its type in the West Indies. He also reminded MacFarlan to recommend him to William Montagu, the Governor of Jamaica, in order to further his own position on the island and also to promote the interests of the Kirk. Steele requested closer connections with the colonial government which, he hoped, would bring ecclesiastical relief for the Scottish presbyterians of Kingston. ${ }^{1}$ This correspondence reveals social, political and religious networks between Scotland and Jamaica in the colonial period. The principal connection between the two nations, however, was transatlantic commerce based upon the trade in slavegrown produce. The links between Glasgow and Kingston were both commercial and ecclesiastical, although the latter have received much less scholarly attention.

The Steele-MacFarlan correspondence also revealed perceptions towards Scottish presbyterianism amongst elite individuals in Jamaica. The Rev. James Steele suggested most influential positions on the island were occupied by Englishmen or Jamaican born Creoles, many of whom worshipped in the Anglican Church, the established

\footnotetext{
${ }^{1}$ University of Glasgow Special Collections (hereafter UGSPc), MS Gen 1717/2/7/1.
} 
faith on Jamaica from 1661. According to Steele, the Anglicans viewed the Church of Scotland as an 'innovation' thus classing it as a dissenting faith on the island. These popular views underpinned formal opposition to the advance of Scottish presbyterianism on Jamaica in the early nineteenth century. Paradoxically, the powerful influence of Scottish presbyterianism across the British Empire has long been recognised. For example, Protestant Foreign Missions and a missionary workforce provided religious and educational instruction in what has been described a 'civilising' mission across the globe. J.H. Proctor and Iain Whyte have both noted the role of Scottish missionaries in Jamaica in the $1820 \mathrm{~s}^{2}$

Scots were, of course, an extremely mobile breed who also established settler churches in America, India, New Zealand, South Africa and Canada. However, according to a recent survey of Scots Churches across the Empire, much remains to be understood about these institutions particularly presbyterian churches in the Caribbean. ${ }^{3}$ This article addresses this lacuna through an examination of the Scots presbyterian kirk in colonial Kingston, Jamaica. What were the motives of the founders in 1819? Who were the driving forces and congregation? What was the reaction from the Established Church and representatives in the House of Assembly of Jamaica, the island's colonial legislature? What was the relationship, if any, between the enslaved and free sections of the presbyterian population?

The establishment of the Scots Kirk should be viewed in the context of large numbers of Scots migrating to the West Indies in the colonial period. Perhaps up to 20,000 Scots (temporary economic migrants known as sojourners) departed for the Caribbean in the

\footnotetext{
${ }^{2}$ Iain Whyte, Scotland and the Abolition of Black Slavery, 1756-1838, (Edinburgh: Edinburgh University Press, 2006), pp.213-247; J.H. Proctor, 'Scottish missionaries and Jamaican slaveholders', Slavery \& Abolition, 25/1, pp. 51-70.

${ }^{3}$ Esther Breitenbach, 'Scots Churches and Missions', in Scotland and the British Empire, ed. by T.M. Devine and John M. MacKenzie, (Oxford: Oxford University Press, 2011), p. 203.
} 
period 1750-1799. ${ }^{4}$ The main destination for Scots in the Caribbean was Jamaica. Many travelled to undertake work as merchants, planters or tradesmen. Others were doctors, missionaries and clergymen. Indeed, the first three ministers of the Scots Kirk between 1819 and 1842 matriculated at Old College. ${ }^{5}$ According to the planter-historian Edward Long, Scots or those of Scottish descent represented a disproportionately powerful minority on Jamaica in 1774, comprising around one third $(6,000$ of 18,000$)$ of the white population. ${ }^{6}$ In terms of their spiritual needs, it seems this large community initially frequented the local Anglican Church although by the late eighteenth century, the need for a dedicated place of worship was recognised. ${ }^{7}$

Michael Morris has cited the subsequent establishment of the Scots Kirk in Kingston as a qualified example of 'fratriotism', a term Murray Pittock applied to patriotic Scottish fraternities abroad who strived to preserve their national identity in the public realm. ${ }^{8}$ That several Scots Kirks were built across the region towards the end of Caribbean slavery seems to support this view. A Scots presbyterian church was established in Demerara around 1817. The foundation stone of the presbyterian church in St George's, Grenada was laid on 30 November 1831. A presbyterian church was established in Trinidad in 1836. It is no coincidence these four colonies in the British West Indies were amongst the most important destinations for Scots sojourners. But what were the motives for constructing the first presbyterian kirk on Jamaica?

\footnotetext{
${ }^{4}$ Douglas Hamilton, 'Patronage and Profit: Scottish Networks in the British West Indies, c.1763-1807' (Unpublished PhD Thesis, University of Aberdeen, 1999), p. 36-7.

${ }^{5} \mathrm{~W}$. Innes Addison, The Matriculation Albums of the University of Glasgow, From 1728 to 1858, (Glasgow: James Maclehose and Sons, 1913), p. 228, 234, 241.

${ }^{6}$ Edward Long, The History of Jamaica, vol. 2, (London, 1774), p. 287.

${ }^{7}$ The Royal Gazette (hereafter TRG), 28 January - 4 February 1815, p. 10.

${ }^{8}$ Michael Morris, Scotland and the Caribbean, c.1740-1833: Atlantic Archipelagos, (New York: Routledge, 2015), p. 20.
} 
The minutes of the Scots Kirk, now held in Jamaica National Archives, reveal much about the early years. In December 1813, a group of Scottish presbyterians petitioned the Mayor and Aldermen in Kingston to request the establishment of a 'Presbyterian place of worship...to accommodate so numerous a community'. ${ }^{9}$ It was not completed until 1819. The Church building itself was based on a grand design. Although building was delayed at times by a lack of funding, various sources of capital were found. Much of the initial finance was donated by Scots in Kingston although subscriptions were received from individuals in St Mary, St Andrew and especially St Thomas in the East which suggests a large Scottish presbyterian community in these parishes.

The campaign to finance the construction of the Kirk began in late 1813. Over two hundred men and firms, mainly based in Kingston, subscribed the 'considerable sum' of over $£ 8000$ Jamaican currency. ${ }^{10}$ By February 1815, the subscribers - described as hailing from 'all classes and denominations' - had paid up seventy per cent of this total. ${ }^{11}$ Some of the highest subscribers, such as George Scheviz, were from Glasgow. Prominent firm, Bogle \& Co., also contributed £200. Another Glasgow merchant, John Miller was named on the first committee with George Scheviz in $1814 .{ }^{12}$ That same year, financial support for 'so laudable an undertaking' was requested from fellowcountrymen in Edinburgh although their response is unknown. ${ }^{13}$ Scots in Jamaica provided funding as well as the expertise required to establish such an institution.

\footnotetext{
9 Jamaica National Archives (hereafter JNA), 5/20/2/1, 'St Andrews Scots Kirk Minutes', 1814, n.p.

${ }^{10}$ JNA, 5/20/2/1, 1814, n.p.

${ }^{11} T R G, 28$ January - 4 February 1815, p. 10.

12 JNA, 5/20/2/1, 1814, n.p.

${ }^{13}$ TRG, 28 January - 4 February 1815, p. 10.
} 
Contemporary newspapers in Jamaica commented on the management of the Scots Kirk. ${ }^{14}$ In late 1814 , twenty five of the most prominent subscribers were nominated as 'fit persons' to become trustees of The Presbyterian Institution of Kingston, a committee formed to manage the Kirk's affairs. ${ }^{15}$ Their role was to manage temporal rather than spiritual concerns such as purchasing and owning real property and the administration of donations. ${ }^{16}$ It is likely the majority of the trustees - such as Andrew Bogle from Glasgow - were born in Scotland. Others hailed from places such as Elgin, Argyll and Lerwick. Many were elite merchants, large scale plantation owners or attorneys such as Francis Graham. Hailing from Cromarty in the north of Scotland, Graham managed slave-plantations on the island. In 1815, he represented 'forty-nine sugar estates, nineteen pens, and ten other plantations, on which there are about thirteen thousand negroes'. He was also part-owner of Tulloch Estate in St Thomas in the Vale. ${ }^{17}$

Many of the trustees had therefore attained positions of some prominence. Although non-conformists had been barred from political office in Jamaica in the $1660 \mathrm{~s},{ }^{18}$ it seems religion did not bar Scottish presbyterians from political office in the 1800s. Some trustees, such as the Hon. John Shand, were members of the Jamaica House of Assembly. It was crucial that trustees were able to exert influence in the Assembly, for as will be demonstrated, some English

14 For some examples, see Patricia Jackson, 'Early $19^{\text {th }}$ century Jamaica', <http://www.jamaicanfamilysearch.com/Samples2/PresbyteriansJamaica.htm $\geq$ [Accessed 20 May 2015].

${ }^{15} T R G, 5-12$ November 1814, p. 17.

${ }^{16}$ TRG, 12-19 November 1814, p. 5.

${ }^{17}$ Further proceedings of the Honourable House of Assembly of Jamaica: Relative to a bill introduced into the House of Commons for effectually preventing the unlawful importation of slaves, and holding free persons in slavery, in the British colonies, (London: J.M. Richardson, and J. Ridgeway, 1816), p. 55.

${ }^{18}$ Keith Hunte, 'Protestantism and Slavery in the British Caribbean', in Christianity in the Caribbean: Essays on Church History, ed. by Armando Lampe, (Kingston: University of West Indies Press, 2001), pp. 90-91. 
representatives were staunch opponents to the spread of presbyterianism.

According to Douglas Hamilton, religious fervour in the Caribbean was aroused when Catholicism stood in opposition to Protestantism. ${ }^{19}$ It seems that around the same time as freedom of worship was granted to Roman Catholics in Kingston, there was an failed attempt to establish a Scottish presbyterian place of worship. ${ }^{20}$ But the attempt to establish a Scots Kirk was more than just a reaction to Catholicism. This was about Scots understanding their status as citizens within the British Empire and having the influence to advance their cause. In 1814, an ambitious bill in the Jamaica Assembly sought legal establishment for the Church of Scotland on Jamaica. ${ }^{21}$ James Steele later noted if the legal establishment were approved it would have put Scottish presbyterianism 'on a footing more suitable to the dignity of the Parent Church of Scotland' and the permanent grants from the government would place the religion on a 'permanently respectable basis'. ${ }^{22}$

Although the bill was rejected, the trustees were able to secure important financial concessions. In 1814, the Jamaica Assembly voted to grant the presbyterian kirk $£ 5000$ island currency to complete their place of worship. Yet two years later construction was still incomplete and although the subscribers had reportedly raised $£ 11,000$ themselves, they petitioned again for a further $£ 3,500$. On 16 December 1816, politicians in the Jamaica Assembly debated the request and one English plantation owner in particular opposed further

19 Douglas Hamilton, 'Transatlantic Ties: Scottish Migration Networks in the Caribbean, 1750-1800', in A Global Clan, Scottish migrant networks and identities since the Eighteenth century, ed. by Angela McCarthy (London, Taurus, 2006), p. 60. ${ }^{20} T R G$, 28 January - 4 February 1815 , p. 10 . There were increasingly tolerant attitudes in the early nineteenth century towards the practising of dissenting faiths on Jamaica. See Mary Turner, Slaves and Missionaries: The Disintegration of Jamaican Slave Society, 1787-1834, (U.S.: University of Illinois Press, 1982), p. 20.

${ }^{21}$ Further proceedings of the Honourable House of Assembly of Jamaica, p. 41.

22 UGSpc, MS Gen 1717/2/7/1. 
funding. Richard Barrett noted although 'vast numbers' of presbyterians in Kingston 'were known to be rich', the Jamaica Assembly had already provided a grant. Barrett also described presbyterianism as a dissenting sect which stood in opposition to the established Episcopalian Church. He warned against 'encouraging a rival that would prove an active enemy' and justified his views:

Their form of worship had been founded in blood, and the overthrow of the fine arts. Under the denomination of Covenanters, they had massacred thousands of their countrymen; they had demolished cathedrals and palaces, and vented their bigoted rage on senseless pictures and statues...In many parts of Scotland...the sour Presbyterian looked with jealousy and hatred on all sects but his own. ${ }^{23}$

Furthermore, according to Barrett, 'the ambition of the sect was to be seen in the magnitude of its Kirk'. Another member of the House, J.C. Pownall, suggested the aim of the presbyterians was to overturn episcopacy by converting 'people of free condition and slaves to their own faith, and thereby... [keeping] down the established religion' ${ }^{24}$ Thus, although the opposition was ostensibly due to financial reasons, it was underpinned by typically sectarian views.

Barrett's vitriolic attack evoked a response from the Scots representatives in the Assembly. John Lunan praised the efficacy of presbyterianism as evidenced by the 'the superior morals and superior information of the lower class of people in Scotland'. Moreover, he noted the large presbyterian community had contributed to the building of other Churches on Jamaica. Lunan also cited the Union of 1707 to support his view that Scottish presbyterianism was established by law although this drew a barbed response from Barret: 'In Scotland it was, but in England and in her Colonies, they were as much dissenters as any other sect. This country, Sir, is Jamaica, not Scotland

\footnotetext{
${ }^{23}$ TRG, 14-21 December 1816, pp. 9-10.

${ }^{24}$ Ibid., p. 10-11.
} 
- It is an English, not a Scotch Colony'. ${ }^{25}$ With such staunch opposition, the vote on the proposed bill was close (16 Ayes, 12 Noes) although the Assembly eventually voted to provide the requested funds. ${ }^{26}$ In the face of strong opposition, Scottish presbyterians secured funding from the Assembly which helped establish a Scots Kirk.

The presbyterian church in Kingston was formally opened on 4 April 1819. The building was octagonal shaped and held 1,000 people, in a period in which the white population of Kingston was around $10,000 .{ }^{27}$ The Rev. James Steele suggested the final cost was 'upwards of $£ 32,000$ ' ${ }^{28}$ The early minutes of the Kirk provide insights into the motives of the founders. The institution was established to provide religious and moral education in order to instil amongst the congregation 'a due sense of religion and morality... and strict observance of good order and decorum and respect for the laws'. Through the Gospel, the founders hoped to replicate the 'good effects' of 'Presbyterian discipline'. ${ }^{29}$ But who worshipped in the Kirk?

In 1822, Rev. James Steele noted 'Presbyterians [in Jamaica] are the more wealthy \& respectable members of society' and his congregation 'in point of rank, intelligence, elegance \& manners... [were the] most respectable I have ever preached to, and they attend more regularly than anywhere I know' ${ }^{30}$ One such worshipper was Michael Scott, a Glasgow merchant in Kingston and later author of Tom Cringle's Log. He was married to the daughter of Robert Bogle, Margaret Cathcart Bogle, and their two daughters were

\footnotetext{
25 Ibid., p. 11.

${ }^{26}$ Votes of the Honourable House of Assembly of Jamaica, October 28 - December 19, 1816 (Jamaica: Alexander Aikman, 1817), p. 162.

27 James Hakewill, A Picturesque Tour of the Island of Jamaica, (London: Hurst and Robinson, 1825), p. 21.

${ }^{28}$ UGSpc, MS Gen 1717/2/7/1.

${ }^{29}$ JNA 5/20/2/1, 1814, n.p.

${ }^{30}$ UGSpc, MS Gen 1717/2/7/1.
} 
both baptised in the Kirk. ${ }^{31}$ Rev. Richard Bickell, Curate of Port Royal and Kingston, described weekly worshipping practices of the period:

The merchants (most of them at least) in Kingston...do go to Church, or kirk, in the morning [of the Sabbath], and drive to their offices or counting-houses to transact business or write letters immediately afterwards; thus making it in reality a day of gain, and having a mere form of religion...It may be truly said, of the greater part of the Jamaica merchants..."Their desk is their Altar, their Ledger is their Bible, and their gold is their God". ${ }^{32}$

Though no friend of slave-owners, Bickell suggested the Scots merchants pursued mammon a little more devoutly than holiness which was fortunate for them as they were laden with a double ecclesiastical burden. Residents of Jamaican parishes were legally obliged to pay taxes, a substantial part of which supported the established Church of England on the island. ${ }^{33}$ In choosing to pursue their faith, presbyterians contributed subscriptions, rents and donations to the Scots Kirk as well as taxes to support an Anglican Church in which they did not worship. It is probable only the wealthy plantocracy were able to afford the privilege.

There is some debate whether the Scots Kirk was a place of worship for black people. The Jamaica Code Noir of 1696, the legal system that regulated lives of the enslaved, decreed that owners should endeavour to provide instruction in the Christian faith to slaves, including baptism. ${ }^{34}$ This was far from widespread, however, as most British planters refused to Christianise their slaves as it promoted notions of equality and humanity which would have

\footnotetext{
31 JNA, 5/20/2/2, 'Marriages and Baptisms', 21 April 1819; 1822, n.p.

32 Richard Bickell, The West Indies as They are: Or, A Real Picture of Slavery: But More Particularly as it Exists in the Island of Jamaica, (London: J. Hatchard \& Sons, 1825), p. 203.

${ }^{33}$ Hunte, 'Protestantism and Slavery in the British Caribbean', p. 88.

${ }^{34}$ Long, The History of Jamaica, vol. 2, p. 491.
} 
encouraged slaves to challenge their unfree status. ${ }^{35}$ The enslaved were viewed as inferior and their condition permanent. The Anglican Church, whose clergy have been described as the adjunct of the planters, did not allow enslaved people to become part of the congregation. ${ }^{36}$ However, ameliorative policies to improve the condition of the enslaved population were gradually introduced across the West Indies from the late eighteenth century and especially after the Abolition of the Slave Trade in 1807. For example, in late 1816, the slave register bill - which necessitated cooperation with the Jamaica Assembly and the British Government - scrutinised the importation of slaves into Jamaica and also promoted the 'moral and religious instruction' of enslaved people on the island. ${ }^{37}$

The Scots Kirk management attempted to gain advantage from this policy. In August 1816, they requested funding from the British Government in order to complete the construction of the Kirk which would have facilitated the 'religious improvement and civilization' of the enslaved population. ${ }^{38}$ It is unknown if the request was successful and in the absence of pew rental records it has proven impossible to verify whether enslaved people worshipped in the Kirk. However, later minutes do refer to the later inclusion of non-white members. In November 1819, the Rev. John Browne was supportive of a petition to the Jamaica Assembly that 'one of the great and most important objects [of the Kirk]... [was that] Ministers should be devoted to the instruction of people of colour and slave population' in order to encourage them to 'attach themselves to the congregation'. ${ }^{39}$ The seating arrangements inside the Kirk also reflected the racial division of colonial society. The lower part of the establishment was set aside

\footnotetext{
${ }^{35}$ Hamilton, 'Transatlantic Ties', p. 60.

36 Mary Turner, 'The Bishop of Jamaica and Slave Instruction', Journal of Ecclesiastical History, 26 (October 1975), p. 378.

${ }^{37}$ Votes of the Honourable House of Assembly of Jamaica, October 28 - December 19, 1816, pp.8-9, pp. 16-20.

${ }^{38}$ TRG, 17-24 August 1816, p. 17.

39 JNA, 5/20/2/1, 1819, n.p.
} 
for white people, the north and south galleries were for 'people of colour', whilst the black population took up the east gallery which was kept 'free of expence', unlike the other sections which attracted charges. ${ }^{40}$ The pew rents were intentionally kept low in some galleries and free in others so as to make religious instruction available to all. Furthermore, in a petition of November 1819, the subscribers requested 'additional provision... be made for the religious instruction of the slaves' especially as a number of them and coloured people now 'resort to the Presbyterian church for religious instruction'. ${ }^{41}$ A later petition stated a 'considerable number' of 'free people and slaves' had joined the congregation and had been 'rescued from their former sectarianism'. ${ }^{42}$

Testimony at House of Commons Select Committees provides some evidence on congregation demographics. In 1832, witnesses were questioned on issues relating to emancipation, including religious instruction. Witnesses testified Churches in Jamaica in general and the Scots Kirk in particular did not provide adequate religious instruction for slaves but instead pretended to do so in order to avert criticism from British abolitionists. ${ }^{43}$ The Reverend John Barry, a Wesleyan Missionary, testified the usual congregation of the Scots Kirk was sixty although, according to him, none were black people. ${ }^{44}$ Another Wesleyan missionary, Reverend Peter Duncan, attended the Scots Kirk frequently yet had never 'saw a slave there'. ${ }^{45}$ These accusations were naturally disputed by the slave-owners. William Shand agreed white people mainly frequented the Kirk and

\footnotetext{
${ }^{40}$ Ibid., 13 March 1822, n.p.

41 Votes of the Honourable House of Assembly of Jamaica, 2 November - 18 December 1819 (Jamaica: Alexander Aikman junior, 1820), pp.93-94, p. 126.

${ }^{42}$ Votes of the Honourable House of Assembly of Jamaica, 31 October 1820- 8 January 1821(Jamaica: Alexander Aikman junior, 1821), pp. 82-83.

43 HCPP 1832, Report from the Select Committee on the Extinction of Slavery Throughout the British Dominions, 11 August 1832, p. 415.

${ }^{44}$ Ibid., p. 91.

45 Ibid., p. 112.
} 
although he suggested 'blacks and browns' attended, he could not provide exact figures. ${ }^{46}$ Given the tensions between planters and preachers on Jamaica in this period, the diametrically opposed views were to be expected. In the 1830s, Jamaican planters viewed evangelical conversion of the enslaved as a threat to the social order and denounced non-conformist missionaries involved in uprisings as traitors. ${ }^{47}$ It was not merely rhetorical opposition. In the aftermath of the Great Jamaican Slave Revolt (1831-32), Wesleyan Churches were demolished whilst the editor of pro-slavery newspaper the Glasgow Courier, James MacQueen, suggested missionaries should be tarred and feathered and driven from the island. ${ }^{48}$ Thus, whilst the accounts of missionaries at the Select Committee were never likely to be sympathetic to slave-owners, it is probable the Scots Kirk was the sole domain of the white presbyterian planter class in the $1830 \mathrm{~s}^{49}$ However, religious instruction in schools was certainly not restricted to white Scots.

Colonial Jamaica was essentially split into two very distinct societies: that of the enslaved and that of free people. However, miscegenation, mainly amongst white Europeans and black enslaved women, led to a 'mulatto' class of people who straddled both societies. Whilst some remained enslaved, others were manumitted as free people of colour. Some were even sent as children to England, Ireland and Scotland for education. ${ }^{50}$ It seems the schools associated with the Scots Kirk catered for both mulatto and white children who remained in Jamaica. According to a petition sent to the Jamaica

\footnotetext{
${ }^{46}$ Ibid, p. 455.

${ }^{47}$ Christer Petley, Slaveholders in Jamaica: Colonial Society and Culture during the Era of Abolition (London: Pickering \& Chatto, 2009), p. 135-6.

${ }^{48}$ William Knibb, Facts and Documents connected with the Insurrection in Jamaica, (London: Holdsworth \& Hall, 1832), p.28.

${ }^{49}$ Whyte, Scotland and the Abolition of Black Slavery, p. 214.

50 Daniel Livesay, 'Extended Families: Mixed-Race Children and Scottish Experience, 1770-1820', International Journal of Scottish Literature, 4 (Spring 2008), p. 12.
} 
Assembly, the committee of the Scots Kirk established schools 'for the education of youth and... of general benefit to the community'. By 1819, two had been founded:

One for the education of children of person of colour in general, and of those especially who may connect themselves with the church, under the superintendence and control of the minister; and another for the education of children of the higher classes of society, under his own immediate care; and both of them are intended to be made as extensively useful as possible, by accommodating the rate of charge to the ability of all ranks of society. ${ }^{51}$

The Rev. James Wordie was the main influence behind this educational mission. After the sudden death of his predecessors, he was ordained as full time minister in December 1823 and remained in Jamaica for twenty years. He was instrumental in the establishment of the island's first Sunday school in $1824 .^{52}$ In its first year, the number of children in attendance - said to be composed from the 'poorer classes of people in Kingston' - increased sharply from 72 to $320 .{ }^{53}$ Despite the 'slender funds' of the Kirk, the schools were praised as a 'very laudable example' to other more wealthy Churches in Jamaica. ${ }^{54}$ By 1832, Sunday schools were associated with most 'places of public worship' across Jamaica. ${ }^{55}$

The Rev. Wordie based his Sunday school system on plans recommended by the Rev. Dr Thomas Chalmers, the celebrated

\footnotetext{
51 JNA, 5/20/2/1, 1818-1819, n.p.

${ }^{52}$ Hew Scott, Fastie Ecclesiae Scoticanae, New Edn., Vol VII, (Edinburgh: Oliver \& Boyd, 1920), pp. 668-671.

${ }^{53}$ Reverend George Wilson Bridges, Annals of Jamaica, Vol. II., (London: John Murray, 1828), pp. 490-491.

${ }^{54}$ TRG, 28 October - 4 November 1826, pp. 18-19.

${ }^{55}$ HCPP, 1831-32 (481) Jamaica: religious instruction. Return to an address to His Majesty, 6 April 1832, p. 2.
} 
Scottish evangelical minister. ${ }^{56}$ The Wordian vision for Kingston was therefore shaped in Glasgow. In the 1810s, Wordie attended Old College, within walking distance of the Tron Kirk at the Trongate where Chalmers was appointed in 1815. It is possible the young student theologian was influenced by Chalmers in this period. Callum Brown has described the Chalmerian system of voluntary organisation as part of a 'Salvation industry'. ${ }^{57}$ This encapsulates the system Wordie implemented in the Scots Kirk. In these schools, attendees were to be shown 'the scheme of salvation...the path of duty...and [dissuaded] from vice by the threatenings of the Gospel'. ${ }^{58}$ Furthermore, 'temporal advantage' was bestowed on children 'whom parents have neglected' by training them up in the 'good principles' that might lead a 'life of usefulness'. This mission was undertaken by teachers, principally 'respectable females of colour', whilst the children were described as the 'youth of free condition'. That is, both teachers and pupils were individuals of mixed European and African descent, although not enslaved. The children were placed in classes according to ability and the English alphabet was taught to those who were illiterate. ${ }^{59}$ Not surprisingly, the Bible was the 'chief book', and passages were assigned to children dependent on their level. ${ }^{60}$ According to the weekly Kingston newspaper, the Royal Gazette founded by a Scottish presbyterian Alexander Aikman and obviously sympathetic to the Kirk - it was hoped these activities would train the children to pursue careers in the establishments of trade and commerce in Kingston. ${ }^{61}$ However, the trustees of the Scots Kirk perhaps had an ulterior motive too.

\footnotetext{
${ }^{56}$ TRG, 12- 19 August 1826, p. 17.

${ }^{57}$ Callum G. Brown, Death of Christian Britain, (London: Routledge, 2013), pp. 4347.

${ }^{58} T R G, 19-26$ January 1828, p. 17.

${ }^{59}$ TRG, 12- 19 August 1826, p. 17.

${ }^{60}$ TRG, 13- 20 January 1827, p. 17.

${ }^{61} T R G, 19-26$ January 1828 , p. 17
} 
D.A. Dunkley has argued that religious and educational instruction provided by the Anglican Church on Jamaica was designed to keep the enslaved population permanently subjugated in slavery. ${ }^{62}$ Similarly, the evidence here suggests the Scots Kirk and associated schools did not represent a challenge the colonial system. However, instead of providing education to the enslaved, the Sunday schools prepared mulatto children for life in white colonial society which maintained a relatively privileged status, in some cases. It is not difficult to imagine the free mulatto sons and daughters of resident Scotsmen attending schools part funded by congregational donations. These funds might be regarded as conscience-money.

The Scots Kirk depended on public and government patronage to support the dissemination of religion amongst the poor. One episode in January 1827 provides an example of voluntary organisation. In an impassioned sermon, the Rev. Wordie pleaded for financial support from the congregation for the upkeep of Sunday schools. Ten members of the congregation formed a 'Penny Society' in order to collect funds on a weekly basis, whilst $£ 85$ currency was collected on the day. ${ }^{63}$ Whilst Chalmers and the congregation of the Tron Kirk strived to save the poor of Glasgow through voluntary activities and donations, Wordie and the Scots Kirk congregation offered salvation to the lower orders of Kingston through similar means. This perhaps marked the beginning of the exportation of the Chalmerian system to the West Indies. This model based on voluntary organisation would become widespread amongst Protestant congregations across the British Empire by the 1850s. ${ }^{64}$

The proceedings of the Jamaica Assembly suggest that Scottish presbyterianism was increasingly tolerated in the colony by the mid1820s. After a request from the Scots Kirk committee in 1824, the Assembly voted to grant $£ 500$ currency as remuneration for James

\footnotetext{
62 D.A. Dunkley, Agency of the Enslaved, (Maryland: Lexington Books, 2013), p. 54.

${ }^{63}$ TRG, 13- 20 January 1827 , p. 17

${ }^{64}$ Brown, Death of Christian Britain, p. 46.
} 
Wordie on account of his 'assiduity in the education of the youth' in Kingston. ${ }^{65}$ In 1827 , the same sum was once again awarded to Wordie for the same reason. ${ }^{66}$ The Assembly seems to have awarded an almost permanent grant to the Scots Kirk for the upkeep of the institution. In 1829, the Kirk's committee pleaded for the 'aid of the house' and blamed their dire economic situation on the death and removal of many presbyterian families from Kingston which meant pew-rents had decreased by one half. The content of the petition also suggested a change of opinion towards the Kirk 'whose usefulness has received approbation, and whose exertions are acknowledged to be of essential importance to the interests of religion and morals, and enable it to go on preparing the young for a career of virtue'. Education was therefore cited as one of the reasons to provide funding. The request was debated by a special Assembly committee and their response was revealing. The committee reported 'the kirk of Scotland in Kingston tends greatly to promote the cause of Christianity' and recommended an award of $£ 1000$ currency. ${ }^{67}$ Almost identical petitions were sent to the Assembly in November 1830 and October 1831. The standardised request for institutional support suggests the process had become a formality. In 1831, the Assembly again awarded $£ 1200$ to be divided amongst the Kirk, the Presbyterian Institution and school. ${ }^{68}$

Whilst Scottish presbyterianism was not granted legal establishment on Jamaica in this period, educational provision offered by schools led to the award of annual funds which conferred the respectability the Scots so desperately craved. More presbyterian institutions were also established across the island. After residents of St Thomas in the East contributed $£ 150$ to the Scots Kirk in Kingston

65 Votes of the Honourable House of Assembly of Jamaica, 2 November - 18 December 1824 (Jamaica: Alexander Aikman junior, 1825), pp.109-110, p. 224.

66 Votes of the Honourable House of Assembly of Jamaica, 13 November - 21 December 1827 (Jamaica: Alexander Aikman junior, 1828), p.90, p. 164.

${ }^{67}$ Votes of the Honourable House of Assembly of Jamaica in a Session, 3 November 1829 - 20 February 1830 (Jamaica: Alexander Aikman junior, 1830), p. 87, 224, 233. ${ }^{68}$ HCPP 1832, Report from the Select Committee on the Extinction of Slavery, p. 524. 
in 1827, a newspaper reported 'it is gratifying to see a community of Scotch people, congregated together in a foreign land...testifying their attachment to the worship of their fathers, and country'. ${ }^{69}$ In return, Rev. James Wordie assisted the development of another Scots Kirk in St Thomas in the East in 1832. In a two period, Wordie toured the island putting 'into operation no less than six new Churches, built...solely by private subscriptions'. ${ }^{70}$ Clearly, Scottish presbyterianism on Jamaica was increasingly tolerated and by 1843 , the island congregation numbered $2,000 .^{71}$

This study of the Scots Kirk of colonial Kingston, the first of its type in the Caribbean, reveals that Scottish sojourners exported organised religion to Jamaica. Many of Glasgow's merchants provided start-up funds in 1814, whilst the first Ministers of the Scots Kirk were trained at Old College. This article also demonstrates Anglicans were still opposed to multiconfessional society in early nineteenth-century Jamaica and this could have been a significant factor in the late arrival of presbyterian places of worship. The opposition was subsequently overcome in various ways. The subscribers and trustees of the Kirk - Scots and individuals of Scottish descent - were able to attract large scale funding from the expatriate community and the Jamaica Assembly. That the Scots Kirk was even constructed at all should be viewed as an example of the increasing financial strength and political influence of Scottish presbyterians in an Anglo-Caribbean society.

One of the main aims of the founders of the Scots Kirk was to replicate presbyterian discipline on Jamaica. The evidence here minutes and petitions - at first seems to suggest the Scots Kirk catered for both the needs of the white plantocracy and the enslaved. However, it is difficult to believe the accounts of slave-owners who had an ulterior motive to portray the Kirk as an inclusive place of

${ }^{69} T R G, 14-21$ April 1827, p. 19.

${ }^{70}$ TRG, 6-13 October 1832.

71 James Mursell Phillippo, Jamaica: Its Past and Present State, (London: John Snow, 1843), p.295. 
worship. The article identifies the exportation of the Chalmerian system to the West Indies. This model of voluntary organisation through privately funded Sunday schools - catered for the free coloured children of Kingston which illustrates an inherent hypocrisy in Jamaican society. The black enslaved people of Jamaica were not deemed worthy enough to be included in the Church congregations but the women were evidently worthy sexual partners. By educating the mulatto sons and daughters of Kingston, the Kirk's schools, funded by conscience money, facilitated a hands-off compromise that salved the conscience of the white Scottish plantocracy class. The schools received much approbation and eventually attracted annual funding from the Jamaica Assembly in an era when non-conformist missionaries were threatened with violence and their chapels destroyed. Evidently, to the plantocracy class, Scottish presbyterianism was a more palatable option than other dissenting faiths on Jamaica that represented a challenge to the social order. Although the quest to gain legal establishment was unsuccessful, the funds conferred respectability on what was previously deemed a dissenting faith. Indeed, with the toleration of Scottish presbyterianism on Jamaica, one of the quintessential AngloCaribbean colonies became British at last. 